\title{
EVALUASI SISTEM PEMBINAAN, PENATAUSAHAAN, DAN PENGAWASAN PENGELOLAAN BARANG MILIK DAERAH PADA BPK-BMD DI PEMERINTAHAN KABUPATEN MINAHASA
}

\author{
Astrid Claudia Sumual $^{1}$, David Paul Elia Saerang ${ }^{2}$, I Gede Suwetja ${ }^{3}$ \\ 1,2,3 Jurusan Akuntansi, Fakultas Ekonomi dan Bisnis, Universitas Sam Ratulangi, Jl. Kampus Bahu, Manado, \\ 95115, Indonesia \\ E-mail : acsumual@gmail.com
}

\begin{abstract}
The management of local asset is part of the regional financial management. Since the enactment of regulation of asset management area is expected to be a reference and strength of local government in managing its regional asset. To apply the system in accordance with Permendagri No.19 year 2016 supervision and coorperation required to carry out the process of recording asset at SKPD level as well as management of regional assets including BPK BMD Minahasa district. The purpose of this study is to find out how the application on the system of coaching, administration, and supervision of goods in the management of local assets in BPK BMD Minahasa whether in accordance with Permendagri No.19 year 2016. The method used in this research is descriptive qualitative analysis method. The results showed that the implementation management of local asset, especially the coaching, administration, and supervision of assets in BPK BMD Minahasa accordance with Permendagri No.19 yaers 2016. Not yet supported IT equipment that has not been compatible with that asset user and the lack of human resources becomes an obstacle asset management in BPK BMD Minahasa.
\end{abstract}

Keywords: asset, coaching, administration, supervision

\section{PENDAHULUAN}

Lahirnya prinsip good governance menuntut pemerintah, baik pemerintah pusat maupun pemerintah daerah harus membuat laporan keuangan yang transparan dan akuntabel. Tujuan utamanya adalah agar semua yang dilaporkan baik barang milik negara atau barang milik daerah harus bisa dipertanggungjawabkan secara keseluruhan dan tepat sesuai tujuan.

Pelaksanaan pengelolaan barang milik daerah tidak semudah yang dibayangkan, karena masih ada faktor yang menjadi kendala, masih banyak instansi yang belum dapat menyajikan data secara pasti, berapa sesungguhnya nilai aset tersebut (Sufri, 2012). Dalam pengelolaan asset daerah secara professional dan modern dengan mengedepankan good governance diharapkan mampu meningkatkan kepercayaan pengelolaan keuangan dari masyarakat.

Pengelolaan Barang Milik Daerah harus di kelola dengan baik sesuai dengan peraturan pemerintah yang berlaku, karena Pengelolaan Barang Milik Daerah berpengaruh terhadap nasib suatu daerah, suatu daerah dapat menjadi daerah yang memiliki sumber daya yang memadai serta mampu dalam pengembangan dan pembagunan daerah tergantung pada cara Pengelolaan Barang Milik Daerah.

Di BPK-BMD di Kabupaten Minahasa terkait pemeriksaan laporan keuangan dari BPK RI sudah meraih opini wajar tanpa pengecualian (WTP), tanggapan BPK terkait Pengelolaan Barang Milik Daerah di BPK-BMD Kabupaten Minahasa memang sudah ada perbaikan yang sesuai terkait objek pemeriksaan, tetapi masih mendapatkan catatan evaluasi perbaikan terhadap pengelolaan barang milik daerah untuk lebih baik lagi, karena masih ditemukan juga adanya aset dalam hal ini tanah yang tidak bersertifikat, adanya jalan yang 
masih kurang bagus, dan kendaraan dinas di saat apel pemeriksaan ada yang tidak hadir, dan catatan terhadap pembinaan dan pengawasan yang ada untuk lebih ditingkatkan lagi.

Pemerintah daerah harus memperhatikan setiap aspek yang akan dilaporkan dalam laporan pertanggungjawaban, pemerintah juga harus memeriksa kembali penatausahaan aset dalam hal ini barang milik daerah apakah sudah sesuai dengan peraturan perundangundangan atau tidak (Tumarar, 2015). Dalam Pengelolaan barang milik daerah di BPK BMD Kabupaten Minahasa mengacu pada peraturan terbaru yaitu Permendagri No.19 Tahun 2016 dan Standar Akuntansi Pemerintahan dalam hal ini aset tetap.

Sering menjadi kendala dalam pengelolaan asset daerah yaitu kesiapan dari setiap satuan kerja perangkat daerah (SKPD) dalam pemeriksaan atau pengecekan barang karena masih ada kesalahan dalam hal pencatatan asset dan kurangnya data-data pendukung yang akan dilaporan dalam laporan pertanggungjawaban dan masih kurangnya SDM (sumber daya manusia) di tingkat pengelola barang.

Berdasarkan latar belakang masalah yang telah diuraikan, maka penulis merumuskan masalah yang akan di bahas yaitu apakah sistem Pembinaan, Penatausahaan, dan Pengawasan Pengelolaan Barang Milik Daerah pada BPK BMD Kabupaten Minahasa sesuai dengan Permendagri No.19 Tahun 2016, dan bagaimana penerapannya ?

Tujuan penelitian ini adalah untuk mengetahui apakah penerapan sistem pembinaan, penatausahaan, dan pengawasan barang dalam pengelolaan barang milik daerah pada BPK BMD Minahasa apakah sudah sesuai dengan Permendagri No.19 Tahun 2016.

\section{TINJAUAN PUSTAKA}

\subsection{Pengertian Akuntansi}

Pontoh (2013: 8) mendefinisikan akuntansi adalah sebuah sistem informasi yang dirancang oleh sebuah organisasi untuk mengidentifikasi (analisis, mencatat, dan meringkas) aktivitas-aktivitas yang mempengaruhi kondisi dan kinerja keuangannya, kemudian mengkomunikasikan hasilnya kepada pengambil keputusan, baik dari internal maupun eksternal organisasi.

\subsection{Akuntansi Sektor Publik}

Mahsun (2013:5) mengatakan bahwa Akuntansi sektor publik seringkali dipahami sebagai segala sesuatu yang berhubungan dengan kepentingan umum dan penyediaan barang atau jasa kepada publik yang dibayar melalui pajak atau pendapatan negara lain yang di atur dengan hukum, dan akuntansi sektor publik merupakan salah satu bidang ilmu yang perkembangannya sangat pesat dalam beberapa tahun terakhir.

\subsection{Pemerintahan daerah}

Berdasarkan UU No.32 Tahun 2004 tentang Pemerintah Daerah, adalah penyelenggaraaan urusan pemerintahan oleh pemerintah daerah dan DPRD, menurut asas otonomi dan tugas pembantuan dengan prinsip otonomi seluas-luasnya dalam sistem dan prinsip NKRI, sebagimana dimaksud dalam UUD 1945. Penyelenggara Pemerintahan Daerah: Gubernur, Bupati, Walikota, dan perangkat daerah lainnya.

\subsection{Standar akuntansi pemerintahan}

Sistem Akuntansi Pemerintahan berdasarkan PP 71 Tahun 2010, standar akuntansi pemerintahan adalah prinsip-prinsip akuntansi yang diterapkan dalam menyusun dan menyajikan laporan keuangan pemerintah.

\subsubsection{Sistem akuntansi pemerintahan}

Sistem Akuntansi Pemerintahan pada Pemerintah Pusat di atur dengan Peraturan Menteri Keuangan yang mengacu pada pedoman umum Sistem Akuntansi Pemerintahan. 


\subsubsection{Sistem akuntansi pemerintah daerah}

Berdasarkan ketentuan Pasal 96 Peraturan Pemerintah Nomor 58 Tahun 2005 tentang Akuntansi Keuangan Daerah. Sistem akuntansi pemerintah daerah meliputi serangkaian prosedur, mulai dari proses pengumpulan data, pencatatan, penggolongan, dan peringkasan atas transaksi dan/atau kejadian keuangan serta pelaporan keuangan dalam rangka pertanggungjawaban pelaksanaan APBD yang dapat dilakukan secara manual atau menggunakan aplikasi komputer.

\subsubsection{Sistem akuntansi SKPD}

Sistem akuntansi SKPD ini dilaksanakah oleh PPK, SKPD, akuntansi realisasi belanja SKPD merupakan bagian dari sistem akuntansi SKPD tersebut. (Tanjung, 2013:160)

\subsection{Aset tetap}

\subsubsection{Pengertian Aset tetap}

Nordiawan dkk, (2012:229), menyatakan bawah asset tetap adalah asset berwujud yang mempunyai masa manfaat lebih dari 12 bulan untuk digunakan dalam kegiatan pemerintahan atau dimanfaatkan oleh masyarakat umum.

\subsubsection{Pengakuan asset tetap}

Di dalam PSAP No.7 Tahun 2010 dijelaskan untuk dapat diakui sebagai aset tetap harus dipenuhi kriteria sebagai berikut:

1. Berwujud

2. Mempunyai masa manfaat lebih dari dua belas bulan.

3. Biaya perolehan aset dapat diukur secara andal.

4. Tidak dimaksudkan untuk dijual dalam operasi normal entitas; dan

5. Diperoleh atau dibangun dengan maksud untuk digunakan.

\subsubsection{Pengukuran aset tetap}

Halim (2013:120), mengatakan bahwa aset tetap dicatat sebesar beban perolehan. Apabila penilaian aset tetap dengan menggunakan biaya perolehan tidak memungkinkan maka nilai aset tetap didasarkan pada nilai wajar pada saat perolehan. Pengukuran dapat dipertimbangkan andal bila terdapat transaksi pertukaran dengan bukti pembelian aset tetap yang menidentifikasikan biayanya.

\subsubsection{Penilaian awal aset tetap}

Barang berwujud yang memenuhi kualifikasi untuk diakui sebagai suatu aset dan dikelompokan sebagai aset tetap, pada awalnya harus diukur berdasarkan biaya perolehan. Bila aset tetap diperoleh dengan tanpa nilai, biaya aset tersebut adalah sebesar nilai wajar pada saat aset tersebut diperoleh.

\subsubsection{Komponen biaya}

Biaya perolehan peralatan dan mesin menggambarkan jumlah pengeluaran yang telah dan yang masih harus dilakukan untuk memperoleh peralatan dan mesin tersebut sampai siap pakai. Biaya ini antara lain meliputi harga pembelian, biaya pengangkutan, biaya instalasi serta biaya langsung lainnya untuk memperoleh dan mempersiapkan sampai peralatan dan mesin tersebut siap digunakan.

\subsection{Barang Milik Daerah (BMD)}

Pengertian yang lebih rinci dan teknis mengenai barang milik daerah dijelaskan dalam Permendagri No.19 Tahun 2016 tentang Pedoman Pengelolaan Barang Milik Daerah pada pasal 3 bahwa:

1. Barang Milik Daerah meliputi :

a. Barang yang dibeli atau diperoleh atas beban APBD

b. Barang yang berasal dari perolehan lainnya yang sah

2. Barang sebagaimana yang dimaksud pada ayat (1) huruf b meliputi:

a. Barang yang diperoleh dari hibah/sumbangan atau yang sejenis

b. Barang yang diperoleh sebagai pelaksanaan dari perjanjian / kontrak 
c. Barang yang diperoleh berdasarkan ketentuan undang-undang

d. Barang yang diperoleh berdasarkan putusan pengadilan yang telah memperoleh kekuatan hukum tetap.

\subsection{Pengelolaan Barang Milik Daerah}

Menurut Peraturan Menteri dalam Negeri No.19 Tahun 2016 Pengelolaan Barang Milik Daerah adalah keseluruhan kegiatan yang meliputi: Pejabat pengelola barang milik daerah, Perencanaan kebutuhan dan penganggaran, Pengadaaan, Penggunaan, Pemanfaatan, Pengamanan dan Pemeliharaan, Penilaian, Pemindatanganan, Pemusnahan, Pengahapusan, Penatausahan, dan Pembinaan, Pengawasan dan Pengendalian

\subsubsection{Penatausahaan Barang Milik Daerah}

Penatausahaan adalah rangkaian kegiatan yang meliputi pembukuan, inventarisasi, dan pelaporan barang milik daerah sesuai dengan ketentuan-ketentuan peraturan perundangundangan (Permendagri No.19 Tahun 2016). Proses Penatausahaan memiliki teknik mencatat yang perlu diketahui petugas pencatat agar memudahkan dalam pencatatannya. Hal yang harus diketahui tersebut yaitu:

1. Asal usul barang

2. Apakah barang dari hasil pembelian atau hibah dari pihak ketiga, dan

3. Dimana barang harus dicatat

\subsubsection{Pembinaan Barang Milik Daerah}

Pembinaan merupakan usaha terkait pengelolaan Barang Milik Daerah melalui pemberian pedoman, bimbingan, pelatihan dan supervisi. Pembinaan dilakukan dalam upaya menjamin kelancaran penyelenggaraan pengelolaan Barang Milik Daerah secara berdayaguna dan berhasilguna. Upaya pembinaan dilakukan melalui pembinaan kepada pegawai yang mengelola BMD dalam bentuk pemberian pelatihan tentang teknis pengelolaan BMD. (Modul Pembinaan, Pengawasan dan Pengendalian)

\subsubsection{Pengawasan Barang Milik Daerah}

Tujuan utama pengawasan dan pengendalian adalah untuk menjamin kelancaran penyelenggaraan pengelolaan BMD secara berdayaguna dan berhasilguna. Untuk mencari tujuan itu maka fungsi pembinaan, pengawasan dan pengendalian sangat penting untuk menjamin tertib administrasi pengelolaan BMD. (Modul Pembinaan, Pengawasan dan Pengendalian). Dalam Permendagri No.17 tahun 2007 tentang Pedoman Teknis Pengelolaan BMD adalah: a. Pengawasan, dan

\subsection{Penelitian Terdahuu}

\section{b. Pengendalian}

Christine Saren (2016) dalam penelitian yang berjudul Evaluasi pengelolaan Barang Milik Daerah pada BPK-BMD Minahasa Utara. Hasil penelitian menunjukkan bahwa Pengelolaan Barang Milik Daerah (BMD) pada (BPK-BMD) Kabupaten Minahasa Utara telah sesuai dengan Permendagri Nomor 19 Tahun 2016.

David Tumarar (2015) dalam penelitian yang berjudul Analisis Penggunaan, Penatausahaan dan Pemanfaatan Barang Milik Daerah Di Pemerintahan Kota Tomohon. Hasil penelitian ini menunjukkan bahwa Penggunaan dan penatausahaan BMD sudah sesuai dengan peraturan, tetapi Pemanfaatan BMD belum berjalan optimal.

\section{METODE PENELITIAN}

\subsection{Jenis dan Sumber Data}

Kuncoro (2013:24) mengatakan bahwa, data adalah keterangan mengenai sesuatu yang diperoleh dalam satu penelitian untuk menjelaskan, menerangkan, dan memecahkan masalah-masalah sesuai dengan konteks judul yang diambil dengan maksud dan tujuan. 
Jenis data yang digunakan dalam penelitian ini adalah data kualitatif. Data yang berupa gambaran umum BPK BMD, dan laporan terkait mengenai penerapan sistem pembinaan, penatausahaan, dan pengawasan pengelolaan BMD. Sujarweni (2014:73) mengatakan bahwa, sumber data adalah subjek dari mana asal data penelitian itu diperoleh. Dalam penelitian ini, penulis menggunakan data primer dan data sekunder.

\subsection{Metode Analisis}

Metode yang digunakan dalam penelitian ini adalah metode analisis deskriptif kualitatif, yaitu suatu metode yang membandingkan antara konsep-konsep teori dan peraturan-peraturan dalam pembinaan, penatausahaan dan pengawasan pengelolaan BMD pada BPK-BMD Minahasa, kemudian menarik kesimpulan dan memberikan beberapa saran yang dianggap perlu. Dalam penelitian ini metode analisis digunakan :

\section{HASIL ANALISIS DAN PEMBAHASAN}

\subsection{Hasil Analisis}

Dalam Pengelolaan Barang Milik Daerah di BPK BMD Kabupaten Minahasa sudah mengacu pada Peraturan Menteri Dalam Negeri Nomor 19 Tahun 2016 tentang Pedoman Penglolaan Barang Milk Daerah. Dalam peraturan tersebut menyatakan bawah yang dimaksud dengan Barang Milik Daerah adalah semua barang yang dibeli atau diperoleh atas beban anggaran pendapatan belanja daerah (APBD) atau berasal dari perolehan lainnya yang sah.

\subsubsection{Pembinaan Barang Milik Daerah}

Berdasarkan hasil wawancara dengan Bpk. John Pantow selaku Kabid Aset Daerah mengatakan dimana "Pembinaan barang milik daerah dilakukan oleh Menteri dalam negeri, dan Pembinaan meliputi pemberian pedoman, bimbingan, pelatihan dan supervisi". Pemberian pedoman merupakan hal penting dalam pelaksanaan Pengelolaan Barang Milik Daerah, karena pedoman merupakan acuan dari pejabat/pelaksana dalam hal pengelolaan/pengurusan Barang Milik Daerah, dalam hal administrasi pemerintahan yang menjelaskan bahwa setiap tindakan atas asset/barang milik daerah harus mendasarkan pada aturan yang jelas.

Selanjutnya Pembinaan juga dilakukan melalui bimbingan seperti sharing khusus bersama dengan pejabat pengurus barang dan pengguna barang terkait dengan masalah dalam Pengelolaan Barang Milik Daerah. Pelaksanaan Pembinaan diikuti juga dengan pelatihan berupa BIMTEK (Bimbingan Teknis).

Kegiatan supervisi ini dapat dilakukan dengan langsung melakukan supervisi ke setiap SKPD yang melaksanakan pengelolaan Barang Milik Daerah, tentunya supervisi/pemantauan ini untuk mengetahui apakah pengelolaan Barang Milik Daerah sudah dilakukan sesuai dengan pedoman atau aturan yang telah ditetapkan. Berdasarkan wawancara dengan Kepala Bidang Aset Daerah dan Pembinaan mengatakan "Pada BPK BMD Kabupaten Minahasa supervisi dilakukan beriringan dengan pelaksanaan Pengelolaan Barang Milik Daerah. Pembinaan supervisi itu dilakukan masih dari BPK BMD sendiri atau unit pengelola barang, tetapi apabila dilapangan ada yang butuh pembuktian itu ditangani langsung oleh teknis contohnya ada disuatu SKPD yang akan melakukan penghapusan barang dan itu diminta untuk dicocokkan sebagai pembuktian yang akan dimasukan dilaporan nantinya".

Pembinaan dilakukan pada level teknis mengharuskan setiap pengguna barang untuk melakukan inventarisasi lagi di setiap SKPD agar bisa membuat setiap data jadi lebih update lagi. Jadi pelaksanaan Pembinaan terkait laporan setiap bulannya, sebagai contoh pada bulan kedua barang yang ada masih dalam keadaan bagus dan pada bulan ketiga barang tersebut sudah rusak jadi selaku pengguna barang harus memasukan itu dalam laporan untuk ditindaklanjuti oleh pengelola barang pada bulan keempat. 


\subsubsection{Penatausahaan Barang Milik Daerah}

Berdasarkan hasil penelitian melalui wawancara dengan staff Pembukuan dan Pendataan BMD mengatakan, "Penerapan Penatausahaan disini telah sesuai dengan Permendagri No.19 Tahun 2016, dimana Penatausahaan adalah rangkaian yang meliputi pembukuan, inventarisasi, dan pelaporan. Kamis sudah mengikuti sesuai dengan aturan yang ada yang dijadikan acuan".

Pembukuan adalah pencatatan barang yang digunakan oleh pengguna barang agar supaya barang yang ada tercatat dengan baik menurut penggolongan sesuai dengan klasifikasinya.

Di BPK-BMD Kabupaten Minahasa setelah pejabat Penatausahaan melakukan pembukuan, dilakukan inventarisasi barang, dari kegiatan inventarisasi barang disusun buku inventarisasi yang menunjukan semua barang yang dimiliki baik yang bergerak maupun tidak bergerak. Proses selanjutnya adalah pelaporan dimana dalam laporan ini terdapat laporan tentang penggunaan barang beserta jumlah serta rekapitulasinya.

Berdasarkan wawancara dengan kepala seksi Pembukuan dan Pendataan BMD mengatakan "Proses Penatausahaan Barang yang ada di BPK BMD Kabupaten Minahasa sudah menggunakan aplikasi SIMDA-BMD. Proses ini diawali dengan membuat pembukuan, dan inventarisasi barang yang dilakukan oleh pengelola barang dan pengguna barang/kuasa pengguna barang secara manual, dan setelah itu data di input ke dalam aplikasi SIMDABMD. Kemudian menghasilkan laporan bulanan Barang Milik Daerah yang akan digunakan sebagai bahan untuk menyusun neraca pemerintahan daerah". Dalam pertanggungjawaban Barang Milik Daerah melalui laporan keuangan daerah khususnya dalam neraca daerah sering terhambat sebagai akibat dari SKPD yang terlambat dalam menyampaikan laporan Barang Milik Daerah ke bidang aset.

\subsubsection{Pengawasan Barang Milik Daerah}

Pengawasan merupakan usaha atau kegiatan untuk mengetahui dan menilai kenyataan yang sebenarnya terjadi mengenai pelaksanaan Pengelolaan Barang Milik Daerah apakah sudah sesuai dengan aturan yang di jadikan acuan atau belum. Berdasarkan wawancara dengan Kabid Aset Daerah dan Pembinaan mengatakan, "dalam pelaksanaan Pengawasan Pengelolaan Barang Milik Daerah di BPK BMD Kabupaten Minahasa di lakukan oleh pengguna barang melalui pemantauan dan penertiban, serta pengelola barang melalui invertigasi. Dalam pengawasan juga mengikuti tingkatan yang ada”.

Dalam pelaksanaan Pengawasan di BPK-BMD Kabupaten Minahasa, pengguna barang melakukan pemantauan dan penertiban terhadap penggunaan, pemanfaatan, pemindahtanganan, penatausahaan, pemeliharaan, dan pengamanan barang milik daerah yang berada dalam penguasaannya. Dalam pelaksanaan pemantauan dan penertiban untuk unit kerja SKPD dilaksanakan oleh kuasa pengguna barang. Sedangkan Pengelola barang melakukan investigasi atas pelaksanaan, penggunaan, pemanfaatan, dan pemindahtangan Barang Milik Daerah dalam rangka penertiban penggunaan, pemanfaatan dan pemindahtanganan Barang Milik Daerah sesuai dengan ketentuan peraturan. Investigasi yang dilakukan ditindaklanjuti oleh pengelola barang dengan meminta aparat pengawasan internal pemerintah untuk melakukan audit atas pelaksanaan, penggunaan, pemanfaatan, dan pemindahtanganan Barang Milik Daerah, selanjutnya hasil audit ditindaklanjuti oleh pengelola barang apakah sesuai dengan ketentuan peraturan perundang-undangan yang berlaku".

Kabid BMD mengatakan "Selaku pejabat penatausahaan barang dan pengurus barang pengelola pengawasan yang ada itu terkait dengan pemanfaatan, mereka mengawasi apakah sudah dimanfaatkan dengan baik atau belum prosedur dalam pengawasan pemantauan dan penertiban, jika terkait dengan investigasi, maka sekertaris daerah selaku pengelola barang itu melakukan pemantauan, kemudian sebagai unit pembantu pengelola Barang Milik Daerah 
membantu pengelola, jika yang di investigasi adalah pengguna barang maka harus ditertibkan, sedangkan jika yang di investigasi adalah pejabat pengelola barang, maka hanya pengamanan saja. Kendalanya dalam pengawasan barang milik daerah itu SDM dalam pengurus barang di tiap SKPD, dan juga ada keterlambatan laporan apabila ada mutasi barang.

\subsection{Pembahasan}

\subsubsection{Pembinaan Barang Milik Daerah}

Berdasarkan hasil penelitian yang dilakukan penulis di BPK BMD Kabupaten Minahasa, pelaksanaan Pengelolaan Barang Milik Daerah sudah mengacu pada Peraturan Menteri dalam Negeri (PERMENDAGRI) Nomor 19 Tahun 2016 tentang pedoman Pengelolaan Barang Milik Daerah.Pembinaan, di BPK BMD Kabupaten Minahasa sudah menerapkan sesuai dengan aturan yang dijadikan acuan, Kepala Daerah (Bupati) sebagai pemegang kekuasaan pengelolaan barang milik daerah berwenang dan bertanggungjawab atas pembinaan dan pelaksanaan pengelolaan barang milik daerah, dan Bpk. John Pantow selaku Kabid Aset Daerah dan Pembinaan juga mengatakan dimana Pembinaan barang milik daerah dilakukan oleh Menteri dalam negeri, adapun bentuk Pembinaan yang sudah di terapkan di BPK BMD Kabupaten Minahasa adalah sebagai berikut:

1. Pemberian pedoman dalam hal penyebarluasan tentang peraturan itu sendiri dalam hal ini Peraturan Menteri Dalam Negeri Nomor 19 Tahun 2016 tentang Pedoman Pengelolaan Barang Milik Daerah. Di bantu dengan pemberian format-format terkait untuk pembahasan dalam pelaporan nanti yang didukung dengan buku-buku berupa modul Pengelolaan Barang Milik Daerah.

2. Sharing khusus dilakukan bersama dengan pejabat pengurus barang serta pengguna barang terkait dengan masalah dalam Pengelolaan Barang Milik Daerah dilapangan, karena setiap SKPD mempunyai kasus yang berbeda dalam pelaksanaan Pengelolaan Barang Milik Daerah. Dalam sharing tersebut langsung membahas mengenai masalah dan pemecahan masalahnya. Sedangkan jika terkait dengan sistem, langsung di konsultasikan dengan BPKP.

3. Melakukan pelatihan berupa BIMTEK (Bimbingan Teknis) pada awal dan akhir tahun. Pembinaan yang berupa pelatihan diperuntukkan bagi pegawai dalam rangka meningkatkan skil/keterampilan dibidang pengelolaan Barang Milik Daerah agar lebih profesional lagi. Jika ada pengurus barang baru, maka selain pemberian BIMTEK ada pula penjelasan khusus, serta konsultasi berupa penjelasan secara rutin kepada pengurus barang baru mengenai pengelolaan Barang Milik Daerah.

4. Pembinaan lewat kegiatan supervisi dilakukan beriringan dengan pelaksanaan Pengelolaan Barang Milik Daerah bukan setelah dilakukannya pekerjaan itu, serta dilihat dari laporan yang ada, jika dalam laporan ditemukan adanya masalah, maka akan langsung ditangani. Contohnya di adakan pemusnahan barang (barang yang sudah masuk virus) langsung dilakukan survei dilapangan dan ditindaklanjuti langsung lewat pemusnahan ijin baru proses administrasi itu lakukan bersama-sama dengan BPK BMD dalam hal ini bagian aset/barang milik daerah.

Jadi dapat disimpulkan bahwa dalam pelaksanaan Pembinaan Barang Milik Daerah di BPK BMD Kabupaten Minahasa sudah sesuai dengan peraturan yang di jadikan acuan yaitu Permendagri No.19 Tahun 2016, tetapi masih ditemukan adanya kendala dalam Pembinaan barang seperti belum didukungnya peralatan berupa IT yang belum sebanding dengan pengguna yang ada, dimana pengguna barang sudah lebih banyak dan pengguna IT masih kurang di setiap SKPD, adapun kendala lain di tiap SKPD yaitu masih kurangnya pengecekan barang untuk update data di setiap pengguna barang, sehingga menjadi kendala juga dalam pembuatan laporan bulanan, serta kendala juga terhadap SDM yang ada. 


\subsubsection{Penatausahaan Barang Milik Daerah}

Berdasarkan hasil penelitian yang dilakukan di BPK BMD Kabupaten Minahasa, Pelaksanaan Penatausahaan Barang Milik Daerah sudah mengacu pada PERMENDAGRI No.19 Tahun 2016 tentang pedoman Pengelolaan Barang Milik daerah. Berdasarkan wawancara dengan Kepala Bidang Aset Daerah dan dan staff Pembukuan dan Pendataan BMD mengatakan, "Dalam Penatausahaan Barang Milik Daerah di BPK BMD Kabupaten Minahasa sudah melakukan tiga tahapan mulai dari pembukuan, inventarisasi, dan pelaporan berdasarkan aturan yang ada.

Dalam pembukuan pengelola barang dan pengguna barang melakukan pendaftaran dan pencatatan barang milik daerah (yang ada dibawah penguasaannya) ke dalam daftar barang pengelola dan daftar barang pengguna menurut penggolongan dan kodefikasi, selanjutnya pengelola barang menyusun daftar barang milik daerah berdasarkan himpunan daftar barang pengguna/daftar barang kuasa pengguna menurut penggolongan dan kodefikasi barang dalam daftar barang milik daerah termasuk juga barang milik daerah yang dimanfaatkan oleh pihak lain.

Selanjutnya untuk Inventarisasi sudah melakukan pendataan, pencatatan, dan pelaporan hasil pendataan barang milik daerah. Dimana Pengguna barang melakukan inventarisasi barang milik daerah paling sedikit satu kali dalam lima tahun dan di BPK BMD Kabupaten Minahasa sudah mengupayakan supaya di setiap laporan bulanan ada inventarisasi yang akan ditindaklanjuti.

Dalam hal Pelaporan, kuasa pengguna barang harus menyusun laporan barang semesteran dan tahunan untuk disampaikan kepada pengguna barang. Kemudian pengguna barang menghimpun laporan barang semesteran dan tahunan dari kuasa pengguna barang yang akan digunakan sebagai bahan untuk menyusun neraca SKPD yang akan disampaikan kepada pengelola barang. Selanjutnya pengelola barang menyusun laporan barang pengelola semesteran dan barang pengelola tahunan, ketahap selanjutnya pengelola barang harus menghimpun laporan barang pengguna semesteran dan laporan barang pengguna tahunan, serta laporan barang pengelola semesteran dan tahunan sebagai bahan untuk penyusunan laporan barang milik daerah dan kemudian laporan barang milik daerah itu akan digunakan sebagai bahan untuk menyusun neraca pemerintah daerah".

Di BPK-BMD Kabupten Minahasa dalam penerapan penatausahaan menggunakan aplikasi SIMDA-BMD, sebelum data di input kedalam aplikasi SIMDA, dilakukan pembukuan dan inventarisasi secara manual, kemudian di input kedalam aplikasi SIMDABMD. Dalam hal ini sudah mengikuti aturan yang dijadikan acuan yaitu Permendagri No.19 Tahun 2016 tetapi masih juga ditemukan kendala dalam pelaksanaanya seperti terlambatnya pelaporan dari setiap SKPD, kurangnya pejabat penatausahaan, dan kendala juga dalam SDM. Solusi yang sudah diterapkan sejauh ini yaitu dari BPK BMD dalam Bidang Aset Daerah dan Pembinaan menindaklanjuti dengan menangani secara langsung.

\subsubsection{Pengawasan Barang Milik Daerah}

Berdasarkan hasil penelitian yang penulis lakukan di BPK BMD Kabupaten Minahasa, penerapan Pengelolaan Barang Milik Daerah sudah mengacu pada Peraturan Menteri Dalam Negeri Nomor 19 Tahun 2016 (PERMENDAGRI No.19 Tahun 2016). Dari hasil wawancara dengan Bpk John selaku Kabid Aset daerah mengatakan, "Pengawasan yang ada terkait dengan pemanfaatan, mereka mengawasi apakah sudah dimanfaatkan dengan baik atau belum prosedur dalam pengawasan pemantauan dan penertiban, jika terkait dengan investigasi, maka sekertaris daerah selaku pengelola barang itu melakukan pemantauan, kemudian sebagai unit pembantu pengelola Barang Milik Daerah membantu pengelola, jika yang di investigasi adalah pengguna barang maka harus ditertibkan, sedangkan jika yang di investigasi adalah pejabat pengelola barang, maka hanya pengamanan saja" hal ini sudah 
sesuai dengan pasal 80 Permendagri No.19 Tahun 2016, dimana Pegawasan dan pengendalian pengelolaan barang milik daerah dilakukan oleh:

1. Pengguna Barang melalui pemantauan dan penertiban dan/atau

2. Pengelola Barang melalui pemantauan dan investigasi.

Pengawasan yang ada di BPK BMD berupa kegiatan pemantauan dan menilai apakah dalam pelaksanaan Pengelolaan Barang Milik Daerah sudah sesuai dengan aturan yang dijadikan acuan atau belum, hal ini di lihat berdasarkan pelaporan yang ada. Dimana BPK BMD pertama melakukan crosscheck disetiap pelaporan yang ada kemudian melakukan investigasi di lapangan untuk penertiban.

Dalam upaya tercapainya sasaran pengawasan maka berbagai sasaran yang harus dicapai melalui kegiatan pengawasan, yaitu :

1. Tugas dan fungsi yang dilaksanakan dalam organisasi bersangkutan benar-benar sesuai dengan pola yang telah digariskan;

2. Struktur dan hirarki organisasi telah sesuai dengan pola dan ketentuan yang ditetapkan;

3. Setiap pejabat/pegawai dalam unit-unit organisasi sungguh-sungguh telah ditempatkan sesuai dengan kemampuannya;

4. Sumber dana dan daya yang telah dimanfaatkan secara ekonomis, efisiensi dan efektif;

5. Prosedur dan tata kerja telah dibakukan dan dalam pelaksanaanya tidak mengalami penyimpangan;

6. Pembagian tugas, wewenang dan tanggung jawab didasarkan pada pertimbangan yang objektib dan rasional;

7. Program dan atau kegiatan ditetapkan dengan pendekatan anggaran yang berbasis kinerja;

8. Tidak terjadi penyalahgunaan (KKN).

Jadi dalam pelaksanaan Pengawasan di BPK-BMD Kabupaten Minahasa dimana Pengguna Barang melakukan pemantauan dan penertiban terhadap penggunaan, pemanfaatan, pemindahtanganan, penatausahaan, pemeliharaan, dan pengamanan barang milik daerah yang berada dalam penguasaannya. Dalam pelaksanaan pemantauan dan penertiban untuk unit kerja SKPD dilaksanakan oleh kuasa pengguna barang. Sedangkan Pengelola Barang melakukan investigasi atas pelaksanaan, penggunaan, pemanfaatan, dan pemindahtangan Barang Milik Daerah dalam rangka penertiban penggunaan, pemanfaatan dan pemindahtanganan Barang Milik Daerah sesuai dengan ketentuan peraturan. Investigasi yang dilakukan ditindaklanjuti oleh pengelola barang dengan meminta aparat pengawasan internal pemerintah untuk melakukan audit atas pelaksanaan, penggunaan, pemanfaatan, dan pemindahtanganan Barang Milik Daerah, selanjutnya hasil audit ditindaklanjuti oleh pengelola barang apakah sesuai dengan ketentuan peraturan perundang-undangan yang berlaku. 
Tabel 4.1 Perbandingan sistem pembinaan, penatausahaan, dan pengawasan

pengelolaan barang milik daerah

\begin{tabular}{|c|c|c|c|}
\hline No & $\begin{array}{c}\text { Pengelolaan BMD di BPK-BMD } \\
\text { Kabupaten Minahasa }\end{array}$ & $\begin{array}{c}\text { Pengelolaan BMD menurut } \\
\text { Permendagri No.19 Tahun } 2016\end{array}$ & Keterangan \\
\hline \multirow[t]{2}{*}{1} & Pembinaan & Pembinaan & \\
\hline & $\begin{array}{c}\text { Kepala Daerah (Bupati) sebagai } \\
\text { pemegang kekuasaan pengelolaan barang } \\
\text { milik daerah berwenang dan } \\
\text { bertanggungjawab atas pembinaan dan } \\
\text { pelaksanaan pengelolaan barang milik } \\
\text { daerah. }\end{array}$ & $\begin{array}{l}\text { Menteri dalam negeri melakukan } \\
\text { pembinaan pengelolaan barang milik } \\
\text { daerah dan menetapkan kebijakan } \\
\text { pengelolaan barang milik daerah. }\end{array}$ & Sesuai \\
\hline \multirow[t]{2}{*}{2} & Penatausahaan & Penatausahaan & \\
\hline & $\begin{array}{l}\text { Penatausahaan di BPK BMD Kabupaten } \\
\text { Minahasa sudah menggunakan aplikasi } \\
\text { SIMDA, sebelum data di input kedalam } \\
\text { aplikasi dilakukan secara manual terlebih } \\
\text { dahulu mulai dari pembukuan, } \\
\text { inventarisasi, dan pelaporan }\end{array}$ & $\begin{array}{l}\text { Rangkaian kegiatan yang meliputi } \\
\text { pembukuan, inventarisasi, dan } \\
\text { pelaporang barang milik daerah } \\
\text { sesuai dengan ketentuan peraturan } \\
\text { perundang-undangan }\end{array}$ & Sesuai \\
\hline \multirow[t]{2}{*}{3} & Pengawasan & Pengawasan & \\
\hline & $\begin{array}{l}\text { Dalam pengawasan hanya pemantauan } \\
\text { dan penertiban, tapi jika terkait } \\
\text { investigasi yang akan ditertibkan } \\
\text { pengelola barang (sekda) hanya } \\
\text { pemantauan dan dibantu oleh BPK BMD } \\
\text { sebagai pengelola barang untuk } \\
\text { investigasi } \\
\text { Untuk tahap-tahap dalam pengawasan itu } \\
\text { diperiksa dulu dari setiap skpd. }\end{array}$ & $\begin{array}{l}\text { Pengguna barang melakukan } \\
\text { pemantauan dan penertiban } \\
\text { terhadap barang milik daerah } \\
\text { yang berada di dalam } \\
\text { penguasaannya } \\
\text { - Pengelola Barang melakukan } \\
\text { pemantauan dan investigasi atas } \\
\text { pelaksanaan pengelolaan barang } \\
\text { milik daerah sesuai dengan } \\
\text { ketentuan peraturan perundang- } \\
\text { undangan. }\end{array}$ & Sesuai \\
\hline
\end{tabular}

Sumber : Olahan data sendiri

\section{KESIMPULAN DAN SARAN}

\subsection{Kesimpulan}

Berdasarkan hasil penelitian dan pembahasan pada fokus penelitian yang penulis temukan, maka dapat disimpulkan bahwa Pengelolaan Barang Milik Daerah dalam hal ini Pembinaan, Penatausahaan, dan Pengawasan penerapannya sudah sesuai dengan Peraturan Menteri Dalam Negeri Nomor 19 Tahun 2016 (PERMENDAGRI) tentang pedoman Pengelolaan Barang milik Daerah.

1. Dalam pelaksanaan Pembinaan di BPK BMD sudah sesuai dengan Peraturan yang di terapkan yaitu Permendagri No.19 Tahun 2016, pembinaan yang ada meliputi pemberian pedoman, bimbingan, pelatihan dan supervisi. Tapi masih ditemukan kendala juga dalam pelaksanaan pembinaan hal ini di lihat dari masih kurangnya SDM, dan ditiap SKPD kurangnya pengecekan barang untuk update data yang ada sehingga terlambat juga dalam pembuatan laporan.

2. Penatausahaan barang yang ada di BPK BMD Kabupaten Minahasa sudah sesuai dengan peraturan yang di jadikan acuan yaitu Permendagri No.19 Tahun 2016, dimulai dari pembukuan, inventarisasi, dan pelaporan. Penatausahaan barang sudah mengunakan aplikasi SIMDA-BMD. Dalam pelaksanaanya terdapat juga kendala dalam hal ini masih kurangnya pejabat penatausahaan barang. 
3. Pengawasan barang di BPK BMD Kabupaten Minahasa sudah sesuai dengan peraturan yang di jadikan acuan yaitu Permendagri No.19 Tahun 2016, dilihat dari pemantauan dan penertiban yang dilakukan oleh pengguna barang, dan investigasi melalui pengelola barang

\subsection{Saran}

Berdasarkan hasil penelitian mengenai Bagaimana penerapan sistem Pembinaan, Penatausahaan, dan Pengawasan barang dalam pengelolaan barang milik daerah di BPK BMD Kabupaten Minahasa, maka berikut saran-saran yang dapat diberikan penulis dalam penelitian ini :

1. Untuk Pembinaan barang di BPK BMD Kabupaten Minahasa lebih ditingkatkan lagi, dengan terus memberikan bimbingan dan pelatihan tentang Pengelolaan Barang Milik Daerah,

2. Dalam Penatausaan barang yang ada di BPK BMD Kabupaten Minahasa terus berpedoman pada peraturan yang dijadikan acuan dan lebih diperhatikan lagi dalam pelaksanaan Penatausahaan barang.

3. Untuk pengawasan yang ada di BPK BMD Kabupaten Minahasa lebih ditingkatkan lagi terhadap pemantauan dan penertiban barang di setiap SKPD

\section{DAFTAR PUSTAKA}

Christine, Saren (2016). Evaluasi pengelolaan Barang Milik Daerah pada BPK-BMD Minahasa Utara. Jurnal EMBA. ISSN 2303-1174 Vol.4 No.4 Hal. 952-963

Halim. 2013. Akuntansi Sektor Publik - Akuntansi Keuangan Daerah. Edisi Keempat. Salemba Empat. Jakarta.

Kuncoro, 2013. Metode Riset untuk Bisnis dan Ekonomi. Penerbit Erlangga. Jakarta

Mahsun, 2013. Akuntansi Sektor Publik. Edisi Ketiga. BPFF. Yogyakarta

Nordiawan. 2012. Akuntansi Pemerintahan. Salemba Empat. Jakarta.

Peraturan Menteri Dalam Negeri Republik Indonesia Nomor 19 Tahun 2016 Tentang Pedomans Pengelolaan Barang Milik Daerah. Jakarta

Peraturan Pemerintah Nomor 58 Tahun 2005. Akuntansi Keuangan Daerah. Jakarta

Peraturan Pemerintah Republik Indonesia Nomor 71 Tahun 2010. Standar Akuntansi Pemerintahan, Penerbit Salemba Empat, 2012. Jakarta

Pontoh, Winston. 2013. Akuntansi : Konsep dan Aplikasi. Halaman Moeka. Jakarta Barat

Republik Indonesia. 2007. Peraturan Menteri Dalam Negeri No. 17 tentang Pedoman Teknis Pengelolaan Barang Milik Daerah. Jakarta

Sufri, Nuryamin (2012). Pegelolaan Aset/Barang Milik Daerah di Dinas Pekerjaan Umum Bantul Tahun 2014-2015. Skripsi Universitas Muhammadiyah Yogjakarta.

Tanjung, Abdul Hafiz. 2013. Akuntansi Pemerintahan Daerah Berbasis Akrual, Cetakan Kedua. Bandung: Alfabeta

Tumarar, David. 2015. Analisis Penggunaan, Penatausahaan dan Pemanfaatan Barang Milik Daerah Di Pemerintahan Kota Tomohon. Jurnal EMBA Vol.3 No.4 Desember 2015. ISSN 2303-1174 . https://ejournal.unsrat.ac.id

Undang-Undang Republik Indonesia Nomor 23 Tahun 2014 Tentang Pemerintah Daerah. Jakarta

V. Wiratna Sujarweni. 2014. Metodologi Penelitian. PUSTAKA BARU PRESS 